\title{
The genetic link between the Azores Archipelago and the Southern Azores Seamount Chain (SASC): The elemental, isotopic and chronological evidences
}

\author{
Luisa Pinto Ribeiro ${ }^{\mathrm{a}, \mathrm{b}, *}$, Sofia Martins ${ }^{\mathrm{c}}$, Anthony Hildenbrand ${ }^{\mathrm{d}, \mathrm{e}}$, Pedro Madureira ${ }^{\mathrm{a}, \mathrm{f}}$, João Mata ${ }^{\mathrm{c}}$ \\ a EMEPC - Task Group for the Extension of the Continental Shelf, R. Costa Pinto 165, 2770-047 Paço de Arcos, Portugal \\ b GeoBioTec Research Center, Univ. Aveiro, Campus de Santiago, 3810-193 Aveiro, Portugal \\ c Instituto Dom Luiz, Faculdade de Ciências, Univ. de Lisboa, 1749-016 Lisboa, Portugal \\ d Univ. Paris-Sud, Laboratoire GEOPS, UMR8148, Orsay F-91405, France \\ e CNRS, Orsay F-91405, France \\ f Dep. Geociências Univ. de Évora/Instituto de Ciências da Terra, R. Romão Ramalho 59, 7000 Évora, Portugal
}

\section{A R T I C L E I N F O}

\section{Article history:}

Received 25 May 2017

Accepted 27 August 2017

Available online 7 September 2017

\section{Keywords:}

Ocean Islands Basalts

Azores mantle source

Southern Azores Seamount Chain

Mid-Atlantic Ridge

\begin{abstract}
A B S T R A C T
New geochemical, isotopic ( $\mathrm{Sr}-\mathrm{Nd}-\mathrm{Hf}-\mathrm{Pb}$ ) and $\mathrm{K}-\mathrm{Ar}$ data, are presented here on samples from the Southern Azores Seamount Chain (SASC) located south of the Azores Plateau. The SASC also includes the Great Meteor, Small Meteor and Closs seamounts, morphologically connected by a saddle at $-4100 \mathrm{~m}$ deep. We conclude that the SASC are characterized by a narrow isotopic variability that falls within the Azores isotopic field. Although each seamount has its own isotopic signature, their mantle source must comprise four local mantle end-members, three of which are common to the Azores, e.g. Plato isotopic signature results from the mixing between HIMU and N-MORB while Great Meteor signature results from this mix with the Azores Common Component (AzCC). A fourth end-member with high ${ }^{208} \mathrm{~Pb} /{ }^{204} \mathrm{~Pb}$ and decoupled $\mathrm{Th} / \mathrm{U}$ ratios $(\Delta 8 / 4$ up to 59.2 ) is identified on Great Meteor northern flank. New K-Ar ages on Plato (33.4 $\pm 0.5 \mathrm{Ma}$ ) and Small Hyeres (31.6 \pm $0.4 \mathrm{Ma}$ ) show nearly coeval volcanism, which is contemporaneous with the E-MORBs erupted at the MAR, drilled on oceanic crust with 30-34 Ma (DSDP82). This study endorses the genetic link between the Azores Archipelago and the SASC to the long-term activity of the Azores plume and the large-scale ridge-hotspot interaction, contributing to better constrain the temporal-spatial evolution of this region of the North Atlantic.
\end{abstract}

(c) 2017 Elsevier B.V. All rights reserved.

\section{Introduction}

Global tomographic studies from seismic stations distributed worldwide have imaged several large-scale, columnar-like low-velocity zones extending from the asthenosphere down to the deep mantle. These structures have been interpreted as the result of ascending mantle plumes, which transfer heat and mass to the upper levels of the Earth (Bijwaard et al., 1998; French and Romanowicz, 2015; Montelli et al., 2006; Yang et al., 2006). Typically, the impingement of ascending plumes transport excess-temperature to the upper mantle and the consequent magmatism (hotspots; Morgan, 1971), promoting the development of linear chains of volcanic islands and seamounts. These are longer and better defined in the cases of a fast drifting lithospheric plate, as is the case of the Pacific plate where $\approx 80$ Ma of magmatic activity produced the $\approx 6000 \mathrm{~km}$ long Hawaii-Emperor Chain, (e.g. Li et al., 2004). Less well defined and shorter lineaments are produced in slow drifting plates such as the

* Corresponding author at: EMEPC - Task Group for the Extension of the Continental Shelf, R. Costa Pinto 165, 2770-047 Paço de Arcos, Portugal.

E-mail address: luisa.pribeiro@emepc.mam.gov.pt (L.P. Ribeiro). cases of the Eurasian and Nubian plates (e.g. Geldmacher et al., 2000; Holm et al., 2008). The lack of a well-defined hotspot track is also observed for the Azores Archipelago and the neighboring seamounts located further south, a region known for the complexity of the lithospheric structures and by the proximity to the triple junction between North America, Eurasian and Nubian lithospheric plates (Gente et al., 2003; Hildenbrand et al., 2014). Geochemical constraints have been used to demonstrate the contribution of a lower mantle reservoir to the Azores mantle source (Madureira et al., 2005, 2014; Moreira et al., 1999; Schaefer et al., 2002; Schilling, 1975), which has been arguably attributed to a deep rooted mantle plume, imaged by several seismic tomography models (Montelli et al., 2006; Yang et al., 2006) and considered to be the cause of source temperatures in excess relatively to the MORB source (Putirka, 2009; Rooney et al., 2012). However, the possible existence of a hydrated or heterogeneous fertilized upper mantle source to explain the excess of magmatism has been pointed out by some authors (Asimow et al., 2004; Beier et al., 2013; Bonatti, 1990; Hildenbrand et al., 2014; Métrich et al., 2014).

The influence of the Azores mantle source is also noticed along the Mid-Atlantic Ridge (MAR), in the vicinity of the Azores islands and 